\title{
POJAM TRAJNOG OBVEZNOG ODNOSA
}

Sažetak: $\quad$ Rad se bavi određenjem pojma trajnog obveznog odnosa. Za to određenje odlučan je pojam trajne obveze te pojmovi trajne činidbe i uzastopnih činidbi. Raspravlja se o pojmu trajne činidbe te o razlikovanju trajne činidbe, jednokratne činidbe $i$ uzastopnih činidbi. Raspravlja se o pojmu uzastopnih obveza i razgraničenju uzastopnih obveza od ispunjenja obveze u dijelovima ili obrocima. Razgraničuju se ugovori s uzastopnim isporukama kod kojih ponavljanja jednokratnih činidbi $i$ protučinidbi u određenim vremenskim razmacima predstavljaju djelomična ispunjenja obveza ugovornih strana te ugovori s trajnom isporukom kod kojih je obveza uzastopnih isporuka trajna obveza čiji je opseg ovisan o vremenu trajanja ugovornog odnosa. Na temelju gledišta razvijenih u njemačkom, austrijskom i švicarskom pravu, zaključuje se da je za hrvatsko pravo prihvatljivo trajne obvezne odnose odrediti kao obvezne odnose u kojima je tipična glavna obveza trajna obveza, odnosno obveza koja za predmet ima trajnu činidbu ili trajno ponavljanje jednokratnih činidbi. Ukazuje se na tipične trajne obvezne odnose te na ključne posebnosti trajnih obveznih odnosa prema obveznim odnosima koji nisu trajni, a koji se nazivaju jednostavnim obveznim odnosima.

Ključne riječi: $\quad$ trajni obvezni odnos, trajna činidba, trajna obveza, uzastopne obveze

\section{UVOD}

Pojam trajnog obveznog odnosa, upotrijebljen u odredbama čl. 211. i čl. 212. Zakona o obveznim odnosima, ${ }^{1}$ u kojima je sadržano opće uređenje prestanka trajnih obveznih odnosa, nije određen odredbama ZOO-a ni drugih propisa hrvatskog pozitivnog prava. Opće određenje pojma trajnog obveznog odnosa nije sadržano ni u pozitivnim propisima austrijskog, njemačkog i švicarskog prava. Učenje o trajnim obveznim odnosima nema odgovarajuće podrijetlo u rimskom pravu, a izraz "trajni obvezni odnosi" (njem. Dauerschuldverhältnisse) je, u odnosu na višetisućljetni razvoj građanskopravne tradicije, relativno novijeg datuma. Prva uporaba tog izraza u njemačkoj pravnoj znanosti pripisuje se Paulu Oertmannu (1910. godine), dok je djelo

\footnotetext{
* Dr. sc. Ivan Tot, Katedra za pravo, Ekonomski fakultet, Sveučilište u Zagrebu, Trg J. F. Kennedyja 6, 10000 Zagreb, Republika Hrvatska. Adresa e-pošte: itot@efzg.hr. ORCID: https://orcid.org/0000-0002-9401-8986. 
Otta von Gierkea iz 1914. godine ${ }^{2}$ prvi sustavni rad o trajnim obveznim odnosima, ${ }^{3}$ a na njemu se temelji i kasniji razvoj učenja o trajnim obveznim odnosima, kako u njemačkom, tako i u švicarskom te austrijskom pravu. U hrvatskom pravu izraz "trajni obvezni odnos" uvriježio se nakon što je u ZOO-u/78 ${ }^{4}$ preuzet izraz "trajni dugovinski odnos" koji je bio upotrijebljen u tzv. Konstantinovićevoj skici. ${ }^{5}$

U hrvatskoj pravnoj književnosti i pravnoj književnosti s područja bivše SFRJ pojam trajnog obveznog odnosa ne određuje se jedinstveno. On se redovito rabi kao istoznačnica s pojmom ugovora s trajnim činidbama, a taj se redovito rabi nasuprot pojmu ugovora s tzv. trenutnim činidbama. Ugovore $s$ trenutnim činidbama najčešće se određuje kao ugovore $u$ kojima se glavne ugovorne obveze sastoje od jedne radnje čijim jednokratnim izvršenjem obveza prestaje, a ugovore s trajnim činidbama kao ugovore u kojima se glavne ugovorne obveze ispunjavaju kontinuiranim radnjama koje se prostiru kroz duže vrijeme. ${ }^{6}$ Pretežno se u pravnoj književnosti u ugovore s trajnim činidbama ubrajaju i ugovori s uzastopnim obvezama, ${ }^{7}$ a njih se redovito određuje kao ugovore u kojima se glavne obveze sastoje od više radnji koje se periodično ponavljaju u određenim vremenskim razmacima. ${ }^{8}$

Redovito se u tom smislu određuju i pojmovi trenutnih i trajnih obveza pa se u pravnoj književnosti pronalaze određenja prema kojima bi trenutne obveze bile one koje se ispunjavaju jednom jednokratnom radnjom, dok bi trajne obveze bile one koje se ispunjavaju poduzimanjem jedne kontinuirane radnje, pri čemu se u trajne obveze ponegdje ubrajaju i sukcesivne obveze koje se ispunjavaju poduzimanjem više uzastopnih radnji. ${ }^{9}$ Nasuprot tome, zastupljeno je i gledište prema kojemu je potrebno razlikovati, s jedne strane, jednokratne i sukcesivne obveze koje se ispunjavaju jedanput ili u više točno određenih radnji, a s druge strane, trajne

2 Gierke von, O., Dauernde Schuldverhältnisse, Jherings Jahrbücher für die Dogmatik des bürgerlichen Rechts, god. 64, 1914., str. 355.-411.

3 Tako: Palandt, O. (red.), Palandt - Bürgerliches Gesetzbuch, Verlag C. H. Beck, München, 2003., str. 514.; Dauner-Lieb, B. i Langen, W. (ur.), BGB - Schuldrecht - Band 2, Nomos, Baden-Baden, 2016., § 314, odl. 6.-7.; Schneider, A., Vertragsanpassung im bipolaren Dauerschuldverhältnis, Mohr Siebeck, Tübingen, 2016., str. 6.-7.

4 Odredbe čl. 357. i čl. 358. Zakona o obveznim odnosima, Službeni list SFRJ, broj 29/1978, 39/1985 i 57/1989, Narodne novine, broj 53/1991, 73/1991, 111/1993, 3/1994, 7/1996, 91/1996, 112/1999 i 88/2001 (dalje: ZOO/78).

5 Taj izraz upotrijebljen je u odredbama čl. 312., čl. 313. i čl. 315. Konstantinovićeve skice: Konstantinović, M., Obligacije i ugovori - Skica za Zakonik o obligacijama i ugovorima, Pravni fakultet u Beogradu, Beograd, 1969., str. 98.-99.

6 Ugovori s trajnim činidbama ponegdje se označavaju i trajnim ugovorima ili ugovorima s trajnim izvršenjem, a ugovori s tzv. trenutnim činidbama ponegdje se nazivaju i trenutnim ugovorima ili ugovorima s trenutnim izvršenjem. U pravnoj književnosti u kontekstu ZOO-a i ZOO/78, usporedi: Cigoj, S., Komentar obligacijskih razmerij - I. knjiga, Časopisni zavod Uradni list SR Slovenije, Ljubljana, 1984., str. 121.; Gorenc, V., Trgovačko pravo - ugovori, Školska knjiga, Zagreb, 1997., str. 42.; Perović, S.; Stojanović, D. (red.), Komentar Zakona o obligacionim odnosima - Knjiga prva, Kulturni centar Gornji Milanovac i Pravni fakultet Kragujevac, Novi Sad, 1980., str. 129. i 898.; Vizner, B., Komentar Zakona o obveznim (obligacionim) odnosima - Knjiga I - Član 1 157, Riječka tiskara, Zagreb, 1978., str. 149.; Vizner, B.; Kapor, V.; Carić, S., Ugovori građanskog i privrednog prava, Riječka tiskara, Rijeka, 1971., str. 88.-89.

7 Naziva ih se i ugovorima sa sukcesivnim činidbama, ugovorima s uzastopnim ispunjenjem te sukcesivnim ugovorima. Usporedi: Cigoj, loc. cit. u bilj. 6; Gorenc, loc. cit. u bilj. 6; Gorenc, V., Zakon o obveznim odnosima s komentarom, RRIF Plus, Zagreb, 1998., str. 173.; Perović, S., Obligaciono pravo - Knjiga prva, Službeni list SFRJ, Beograd, 1981., str. 106.-107.; Perović i Stojanović, op. cit. u bilj. 6, str. 420. i 898.; Radišić, J., Obligaciono pravo - Opšti deo, Savremena administracija, Beograd, 1990., str. 129.; Vizner, loc. cit. u bilj. 6; Vizner et al., op. cit. u bilj. 6, str. 88.

8 Usporedi: Gorenc, op. cit. u bilj. 7, str. 173. i 482.; Kačer, H.; Radolović, A.; Slakoper, Z., Zakon o obveznim odnosima s komentarom, Poslovni zbornik, Zagreb, 2006., str. 367.; Perović, loc. cit. u bilj. 7; Perović i Stojanović, op. cit. u bilj. 6, str. 420. i 898.; Vizner, B., Komentar Zakona o obveznim (obligacionim) odnosima - Knjiga II - Član 158 - 453, Riječka tiskara, Zagreb, 1978., str. 1277.; Vizner et al., op. cit. u bilj. 6, str. 88 . 
obveze u čijoj je prirodi da traju određeno vrijeme. ${ }^{10}$ Prema tom gledištu ugovore je potrebno razvrstavati na ugovore s jednokratnom ili sa sukcesivnim činidbama te na ugovore $s$ trajnom činidbom, pri čemu bi trajan obvezni odnos nastajao samo sklapanjem ugovora s trajnom činidbom, ne i sklapanjem ugovora sa sukcesivnim činidbama. ${ }^{11}$

Ponegdje se podjela ugovora na ugovore s trenutnim i s trajnim činidbama poistovjećuje $\mathrm{s}$ podjelom na kratkotrajne i dugotrajne ugovore, ${ }^{12}$ dok se trenutne obveze poistovjećuju $\mathrm{s}$ kratkotrajnim, a trajne obveze s dugotrajnim obvezama. ${ }^{13}$ Među primjerima ugovora s trajnim činidbama često se navodi i ugovor o kupoprodaji s obročnom otplatom cijene, odnosno općenito ugovori u kojima se novčana obveza ispunjava u obrocima. ${ }^{14}$

U ovom radu preispituju se iznesena stajališta pravne književnosti s ciljem iznalaženja određenja pojma trajnih obveznih odnosa kojim bi se obuhvatila karakteristična obilježja svih takvih obveznih odnosa i kojim bi se trajni obvezni odnosi jasno razgraničili od obveznih odnosa koji nisu trajni obvezni odnosi. Radi toga, u radu se analiziraju gledišta o pojmu, prirodi i posebnostima trajnih obveznih odnosa razvijena u njemačkom, austrijskom i švicarskom pravu. Za određenje pojma trajnog obveznog odnosa odlučan je pojam trajne obveze, a za taj pojam važni su pojmovi trajne činidbe i uzastopnih činidbi. Stoga se u drugom poglavlju najprije raspravlja o pojmu trajne činidbe i pojmu uzastopnih činidbi, a koje je potrebno razgraničiti od pojma jednokratne činidbe, a zatim i o pojmu uzastopnih obveza te o pojmu trajne obveze. U trećem poglavlju pristupa se određenju pojma trajnih obveznih odnosa, dok se u četvrtom poglavlju raspravlja o tipičnim trajnim obveznim odnosima. U petom poglavlju ukazuje se na posebnosti trajnih obveznih odnosa prema obveznim odnosima koji nisu trajni. Zaključci se iznose u šestom poglavlju rada.

\section{JEDNOKRATNA ČINIDBA, TRAJNA ČINIDBA I UZASTOPNE ČINIDBE}

Jednokratna činidba (njem. einmalige Leistung) je radnja koju je dužnik na temelju obveznopravnog odnosa dužan vjerovniku izvršiti jednokratno - odjednom i u potpunosti. ${ }^{15} \mathrm{Ob}$ veze koje za predmet imaju jednokratnu činidbu prestaju ispunjenjem kad dužnik jednokratno izvrši dužnu radnju. Primjerice, činidba davanja stvari kupcu u vlasništvo načelno je jed-

10 Tako: Slakoper, Z.; Gorenc, V.; Bukovac Puvača, M., Obvezno pravo - Opći dio - Sklapanje, promjene i prestanak ugovora, Novi informator, Zagreb, 2009., str. 238.

11 Ibid., str. 239.

12 Tako: Radišić, op. cit. u bilj. 7, str. 128.

13 Usporedi: Gorenc, op. cit. u bilj. 7, str. 482.; Vizner, loc. cit. u bilj. 8.

14 Usporedi: Crnić, I., Zakon o obveznim odnosima, Organizator, Zagreb, 2016., str. 844.; Gorenc, loc. cit. u bilj. 6; Gorenc, op. cit. u bilj. 7, str. 173. i 482.; Vizner, loc. cit. u bilj. 7; Vizner, loc. cit. u bilj. 8; Vizner et al., loc. cit. u bilj. 6.

15 U istom smislu i: Slakoper et al., loc. cit. u bilj. 10. Usporedi, za švicarsko pravo: Gauch, P.; Schluep, W. R.; Schmid, J.; Rey, H., Schweizerisches Obligationenrecht - Allgemeiner Teil - Band I, Schulthess Polygraphischer Verlag, Zürich, 1998., str. 13. Za austrijsko pravo: Bydlinski, P., Bürgerliches Recht - Band I - Allgemeiner Teil, Springer, Wien - New York, 2007., str. 103.; Koziol, H.; Bydlinski, P.; Bollenberger, R. (ur.), Kurzkommentar zum ABGB, Springer, Wien - New York, 2010., str. 298. Za njemačko pravo: Fikentscher, W., Schuldrecht, Walter de Gruyter, Berlin - New York, 1992., str. 39.; Stürner, R. (red.), Jauernig - Bürgerliches Gezetzbuch: Kommentar, C. H. Beck, München, 2015., §311, odl. 14. 
nokratna činidba pa to davanje predstavlja ispunjenje prodavateljeve obveze predati kupcu stvar u vlasništvo i njime prodavateljeva obveza prestaje.

Ako je dužnik na temelju obveznopravnog odnosa ovlašten izvršiti činidbu u više unaprijed točno određenih dijelova, umjesto jednokratno, moguće je govoriti o višekratnoj, višedijelnoj činidbi (njem. mehrmalige Leistung; mehrteilige Leistung) ${ }^{16}$ Obveze koje za predmet imaju takvu činidbu prestaju ispunjenjem kad dužnik izvrši posljednju od točno određenog broja istovrsnih radnji koje samo sve zajedno predstavljaju dužnu činidbu. Primjerice, činidba davanja kupcu u vlasništvo određene količine stvari u unaprijed određenom broju dijelova jest višekratna činidba, a o takvoj činidbi je riječ i pri ispunjenju novčane obveze u unaprijed određenom broju obroka.

Trajna činidba (njem. dauernde Leistung; fortgesetzte Leistung) je radnja koju je dužnik na temelju obveznopravnog odnosa dužan neprekidno, kontinuirano izvršavati. ${ }^{17}$ Obveze koje za predmet imaju trajnu činidbu ne mogu prestati ispunjenjem jer je u prirodi trajne činidbe da se ona kontinuirano izvršava kroz izvjesno vrijeme. ${ }^{18}$ Karakteristični primjer obveze s trajnom činidbom je obveza ostavljanja na uporabu (njem. Belassungspflicht), odnosno prepuštanja uporabe (njem. Gebrauchsüberlassungspflicht). ${ }^{19} \mathrm{Tu}$ je obvezu potrebno razlikovati od jednokratne obveze predaje radi uporabe. Obveza predaje radi uporabe za predmet ima jednokratnu činidbu čiji je sadržaj činjenje, ${ }^{20}$ dok obveza ostavljanja na uporabu, odnosno prepuštanja uporabe za predmet ima trajnu činidbu čiji je sadržaj trpljenje.

O uzastopnim činidbama je riječ ako je dužnik na temelju obveznopravnog odnosa dužan u određenim vremenskim razmacima ponavljati jednokratne činidbe. ${ }^{21}$ Uzastopne obveze su obveze koje za predmet imaju uzastopne činidbe, odnosno ponavljanje jednokratnih činidbi. Ugovori s uzastopnim obvezama ugovori su u kojima se u određenim vremenskim razmacima ponavljaju jednokratne činidbe i jednokratne protučinidbe.

U hrvatskoj pravnoj književnosti ugovori s uzastopnim obvezama često se poistovjećuju s ugovorima s ispunjenjem obveze u dijelovima ili obrocima. Drži se da je o ugovorima s uzastopnim obvezama riječ u slučajevima u kojima se dužna činidba izvršava postupno i djelomično u određenim vremenskim razmacima te da uzastopna obveza prestaje ispunjenjem posljednjeg obroka, a među primjerima ugovora s uzastopnim obvezama navode se ugovori o isporuci

16 Usporedi, za švicarsko pravo: Gauch, P., System der Beendigung von Dauerverträgen, Universitätsverlag Freiburg, Freiburg, 1968. , str. 7. Za njemačko pravo: Fikentscher, loc. cit. u bilj. 15.

17 Usporedi, za švicarsko pravo: Gauch, op. cit. u bilj. 16, str. 6.-7.; Gauch et al., loc. cit. u bilj. 15. Za austrijsko pravo: Bydlinski, loc. cit. u bilj. 15; Koziol et al., loc. cit. u bilj. 15. Za njemačko pravo: Stürner, loc. cit. u bilj. 15.

18 U istom smislu: Slakoper et al., loc. cit. u bilj. 10. Usporedi, za švicarsko pravo: Gauch, op. cit. u bilj. 16, str. 6.-7.; Gauch et al., op. cit. u bilj. 15, str. 21. Za austrijsko pravo: Barta, H. (ur.), Zivilrecht - Grundriss und Einführung in das Rechtsdanken, Facultas Verlags- und Buchhandels, Wien, 2004., str. 390.; Bydlinski, loc. cit. u bilj. 15. Za njemačko pravo: Gierke, op. cit. u bilj. 2, str. 359. i 363 .

19 Usporedi, za švicarsko pravo: Gauch et al., loc. cit. u bilj. 15. Za austrijsko pravo: Dullinger, S., Bürgerliches Recht - Band II Schuldrecht - Allgemeiner Teil, Springer, Wien - New York, 2010., str. 17. Za njemačko pravo: Fikentscher, loc. cit. u bilj. 15; Gierke, op. cit. u bilj. 2, str. 360 .

20 Nije riječ o činidbi davanja jer sadržaj činidbe davanja podrazumijeva da dužnik predajom pribavlja vjerovniku vlasništvo ili neko drugo stvarno pravo. Činidba čiji je sadržaj predaja u detenciju ili posjed je činidba činjenja, a ne davanja. Vidi o tome: Klarić, P.; Vedriš, M., Građansko pravo, Narodne novine, Zagreb, 2009., str. 93.; Slakoper et al., op. cit. u bilj. 10, str. 106.

21 U istom smislu: Slakoper et al., op. cit. u bilj. 10, str. 238.-239. Usporedi, za švicarsko pravo: Gauch, loc. cit. u bilj. 16. Za austrijsko pravo: Bydlinski, loc. cit. u bilj. 15; Dullinger, op. cit. u bilj. 19, str. 43. 
ugovorene količine robe u određenim dijelovima te ugovori s obročnim otplatama. ${ }^{22} \mathrm{U}$ tim slučajevima nije riječ o ugovorima s uzastopnim obvezama, nego o ugovorima u kojima dužnik duguje vjerovniku ispunjenje jedne obveze koju je ovlašten ispuniti u unaprijed točno određenim dijelovima ili obrocima. ${ }^{23}$ Ovisno o tome je li ta obveza nenovčana ili novčana, razlikuju se ugovor s isporukom u dijelovima ili obrocima (njem. Teillieferungsvertrag; Ratenlieferungsvertrag) te ugovor s obročnim otplatama (njem. Ratenzahlungsvertrag; Ratenvertrag). ${ }^{24} \mathrm{Za}$ obje te vrste ugovora karakteristično je da se dužnikova obveza ispunjava u unaprijed određenom i ograničenom broju dijelova ili obroka od kojih svaki predstavlja djelomično ispunjenje obveze, dok se protučinidba izvršava jednokratno, odjednom i u potpunosti.

Za razliku od ugovora s obročnim isporukama ili otplatama, u ugovoru s uzastopnim obvezama, koji se često označava i ugovorom s uzastopnim ili sukcesivnim isporukama (njem. Sukzessivlieferungsvertrag), u određenim vremenskim razmacima se ponavljaju i jednokratne činidbe i jednokratne protučinidbe: za svaku od pojedinih obveza isporuke duguje se protučinidba. ${ }^{25}$ Ugovorom s uzastopnim isporukama može se unaprijed odrediti i ograničiti i broj pojedinih isporuka i broj dijelova ili obroka protučinidbe pa će i u tom slučaju ponavljanja jednokratnih činidbi i protučinidbi u određenim vremenskim razmacima predstavljati djelomična ispunjenja obveza ugovornih strana (riječ je o njem. Teilleistung gegen Teilleistung). ${ }^{26}$ Takav je, primjerice, ugovor o isporuci dvanaest tona žita u dvanaest mjesečnih obroka za koje se cijena također plaća u dvanaest mjesečnih obroka.

Ugovor s uzastopnim isporukama može biti sklopljen i na određeno ili na neodređeno vrijeme tako da broj pojedinih isporuka koje se izvršavaju uzastopno u određenim vremenskim razmacima ili na poziv druge ugovorne strane nije unaprijed određen ni ograničen. ${ }^{27} \mathrm{U}$ takvom ugovoru s uzastopnim isporukama, kojeg se ponegdje naziva i ugovorom s trajnom isporukom (njem. Dauerlieferungsvertrag), obveza uzastopnih isporuka je trajna obveza, a opseg ukupne obveze isporuke ovisan je o vremenu trajanju ugovornog odnosa, pri čemu izvršenje pojedinih od uzastopnih isporuka nema značaj djelomičnog ispunjenja trajne obveze uzastopnih ispo-

22 Usporedi: Crnić, loc. cit. u bilj. 14; Gorenc, op. cit. u bilj. 7, str. 173. i 482.; Vizner, loc. cit. u bilj. 8.

23 Tako i u hrvatskoj sudskoj praksi u odluci: Vrhovni sud Republike Hrvatske (dalje: VSRH), Rev 1081/10-5 od 5. veljače 2013. "S obzirom da predmet ugovora nije svaka pojedina dionica, već 20.303 dionice koje predstavljaju cjelinu, za koje se samo cijena plaća u obrocima, ne radi se o ugovoru s uzastopnim davanjima.". Ta odluka, kao i sve druge u radu citirane odluke iz hrvatske sudske prakse, dostupna je na: VSRH, Sudska praksa - Portal sudske prakse, https://sudskapraksa.csp.vsrh.hr, pristupljeno 15. siječnja 2018.

Prikladno je napomenuti kako je Konstantinovićeva skica među odredbama koje su uređivale raskid ugovora s uzastopnim obvezama sadržavala i odredbu iz koje je izričito proizlazilo da ugovor o kupoprodaji s obročnom otplatom cijene nije ugovor s uzastopnim obvezama. Vidi odredbu čl. 100. st. 3. Konstantinovićeve skice prema kojoj: "Za ugovor o prodaji u kome je uglavljena isplata kupovne cene u obrocima važe posebne odredbe." (Konstantinović, op. cit. u bilj. 5, str. 41.).

Usporedi, za njemačko pravo: Bamberger, H. G., Roth, H., Hau, W. i Poseck, R. (ur.), BeckOK BGB, Verlag C. H. Beck, München, 2017., § 311, odl. 12.; Dauner Lieb i Langen, op. cit. u bilj. 3, § 314, odl. 14.; Fikentscher, loc. cit. u bilj. 15; Krüger, W. (red.), Münchener Kommentar zum Bürgerlichen Gesetzbuch - Band 2 - Schuldrecht - Allgemeiner Teil, Verlag C. H. Beck, München, 2016. $\S 314$, odl. 8 .

25 U tom smislu ugovor o kupoprodaji s uzastopnim isporukama razumijevaju i dispozitivne odredbe čl. 440. ZOO-a o plaćanju cijene u slučaju uzastopnih isporuka.

26 Usporedi, za austrijsko pravo: Dullinger, op. cit. u bilj. 19, str. 43.

27 Usporedi, za austrijsko pravo: Barta, op. cit. u bilj. 18, str. 388.; Dullinger, op. cit. u bilj. 19, str. 43. Za njemačko pravo: Bamberger et al., op. cit. u bilj. 24, § 311, odl. 14. i § 314, odl. 6.; Dauner Lieb; Langen, op. cit. u bilj. 3, § 314, odl. 15.; Krüger, loc. cit. u bilj. 24; Stürner, loc. cit. u bilj. 15. 
ruka. ${ }^{28}$ Kod takvih ugovora potrebno je razgraničiti prestanak ugovornog odnosa u njegovoj ukupnosti kojim prestaje i karakteristična trajna obveza uzastopnih isporuka od prestanka obveza na pojedine od uzastopnih isporuka. ${ }^{29}$ Takav je, primjerice, ugovor o isporuci jedne tone žita na mjesec sklopljen na neodređeno vrijeme.

Pri primjeni odredaba čl. 365. ZOO-a o raskidu ugovora s uzastopnim obvezama potrebno je voditi računa o tome je li u konkretnom slučaju riječ o ugovoru s ispunjenjem obveze u dijelovima ili o ugovoru s uzastopnim isporukama u kojem se činidbe i protučinidbe ponavljaju kao djelomična ispunjenja ugovornih obveza ili pak o ugovoru s uzastopnim isporukama $s$ trajnom obvezom uzastopnih isporuka, a posebno stoga što u potonjem slučaju odredbe čl. 365. ZOO-a ne isključuju primjenu odredaba čl. 211. i čl. 212. ZOO-a. ${ }^{30}$ Valja naglasiti da nije svaki dugoročni obvezni odnos ugovor s uzastopnim obvezama, niti je svaki ugovor s uzastopnim obvezama trajni obvezni odnos, a niti je svaki trajni obvezni odnos ugovor s uzastopnim obvezama što, čini se, nije uvijek jasno u hrvatskoj sudskoj praksi. ${ }^{31}$

Trajne obveze za predmet mogu imati trajnu činidbu, ali i uzastopno ponavljanje jednokratnih činidbi ako je riječ o trajnoj obvezi uzastopnih činidbi. Za trajne obveze karakteristično je da se opseg dužnih činidbi ravna prema vremenskom trajanju obveze, a ne da se vremensko trajanje obveze ravna prema opsegu dužnih činidbi. ${ }^{32}$

Potrebno je razlikovati ugovore s trajnim obvezama i ugovore s obvezama koje nisu trajne obveze, a tu je podjelu ugovora potrebno razgraničiti od podjele ugovora na kratkotrajne ili kratkoročne (njem. kurzfristige Verträge) i dugotrajne ili dugoročne ugovore (njem. langfristige Verträge). Kriterij podjele ugovora na kratkoročne i dugoročne ugovore jest dužina vremenskog razdoblja od trenutka sklapanja ugovora do trenutka prestanka posljednje ugovorne obveze ispunjenjem. ${ }^{33}$ Ugovori s obvezama koje nisu trajne obveze mogu biti i kratkoročni i dugoročni,

28 Usporedi, za austrijsko pravo: Barta, op. cit. u bilj. 18, str. 388.; Dullinger, op. cit. u bilj. 19, str. 43. Za njemačko pravo: Bamberger et al., op. cit. u bilj. 24., § 311, odl. 14. i § 314, odl. 6.; Dauner Lieb; Langen, op. cit. u bilj. 3, § 314, odl. 15.; Fikentscher, loc. cit. u bilj. 15; Gierke, op. cit. u bilj. 2, str. 362.; Krüger, loc. cit. u bilj. 24; Palandt, loc. cit. u bilj. 3; Stürner, loc. cit. u bilj. 15; Zerres, T., Bürgerliches Recht, Springer, Berlin - Heidelberg, 2010., str. 97.

29 Usporedi, za njemačko pravo: Bamberger et al., op. cit. u bilj. 24, § 311, odl. 15.; Gierke, op. cit. u bilj. 2, str. 360.-361.

To je, čini se, u jednom predmetu imao u vidu i VSRH kad je nižestupanjske sudove uputio na utvrđenje je li obveza tuženika prestala na "drugi zakonom predviđeni način", u odluci: VSRH, Revt-18/03-2 od 1. travnja 2003. “(...) proizlazi da je u pitanju ugovor s uzastopnim obvezama budući su tuženici izrezivali, a tužitelj preuzimao dio po dio rezane građe. Kad u takvom slučaju jedna strana ne ispuni jednu obvezu, druga strana može, u razumnom roku, raskinuti ugovor u pogledu svih budućih obveza, ako je iz danih okolnosti očito da ni one neće biti ispunjene (...). Nižestupanjski sudovi su međutim samo konstatirali da su tuženici imali pravo prestati s daljnjim izvršavanjem obveze ne ispitujući jesu li se oslobodili obveze zbog raskida ugovora ili je njihova obveza prestala na neki drugi zakonom predviđeni način."

31 Iz činjeničnog stanja u pojedinim odlukama u kojima su primjenjivane odredbe ZOO-a o raskidu ugovora s uzastopnim obvezama proizlazi da u tim slučajevima ipak nije bilo riječi o ugovorima s uzastopnim obvezama. Tako je u jednoj odluci riječ bila o trajnom obveznom odnosu, no ne i o ugovoru s uzastopnim obvezama: VSRH, Rev-558/1997-2 od 24. kolovoza 2000. “Kako su nižestupanjski sudovi zaključili da su ostvarene pretpostavke za raskid predmetnog ugovora o zajmu pravilnom primjenom materijalnog prava prihvatili su tužbeni zahtjev za raskid toga ugovora, kao i zahtjev da tuženici tužiteljima plate 141.098,99 kn sa zakonskim zateznim kamatama. Naime, prema odredbi čl. 129. st. 1. Zakona o obveznim odnosima (...) kad u ugovoru s uzastopnim obvezama jedna strana ne ispuni jednu obvezu, druga strana može u razumnom roku raskinuti ugovor u pogledu svih budućih obveza, ako je iz danih okolnosti očito da ni one neće biti ispunjene, a prema odredbi čl. 132. st. 2. ZOO-a u slučaju raskida ugovora ako je jedna strana izvršila ugovor potpuno ili djelomično, ima pravo da joj se vrati ono što je dala. Strana koja vraća novac obvezna je platiti zateznu kamatu od dana kad je isplatu primila (čl. 132. st. 5. ZOO-a), no u konkretnom slučaju tužitelji zahtijevaju isplatu zatezne kamate ne od vremena davanja zajma, nego od 1. prosinca 1994. godine." Schuldrecht - Besonderer Teil und Schadenersatz, Springer Verlag, Wien, 1963., str. 46. 
dok su ugovori s trajnim obvezama često, no ne i nužno, dugoročni ugovori. ${ }^{34}$ Primjerice, ugovor o kupoprodaji u kojemu je karakteristična činidba jednokratno davanje stvari kupcu u vlasništvo može biti kratkoročan ugovor, kao i ugovor s tzv. trenutnom obvezom u smislu u kojemu se taj pojam ponegdje rabi u hrvatskoj pravnoj književnosti, ${ }^{35}$ no on može biti i dugoročan ugovor ako je ugovoren duži rok za ispunjenje bilo koje od glavnih obveza ugovornih strana. Ugovor o najmu kao ugovor s trajnom obvezom prepuštanja uporabe često je dugoročan ugovor, no može biti i kratkoročan ugovor, kao što je to slučaj s ugovorom o najmu motornog vozila u rent-a-car poslu.

\section{ODREĐENJE POJMA TRAJNOG OBVEZNOG ODNOSA}

Za hrvatsko pravo prihvatljivo je određenje pojma trajnih obveznih odnosa koje se pronalazi u austrijskom, njemačkom i švicarskom pravu. Trajni obvezni odnosi (njem. Dauerschuldverhältnisse) su obvezni odnosi u kojima je tipična glavna obveza trajna obveza, tj. obveza koja za predmet ima trajnu činidbu ili trajno ponavljanje jednokratnih činidbi. ${ }^{36}$ Karakteristično je za trajne obvezne odnose da je dužnik trajne obveze dužan kontinuirano izvršavati trajnu činidbu ili ponavljati jednokratne činidbe sve dotle dokle trajna obveza ne prestane. Trajna obveza ne može prestati ispunjenjem obveze, već ona prestaje tek prestankom trajnog obveznog odnosa. Naime, trajni obvezni odnosi nisu upravljeni na jednokratnu razmjenu činidbi i na što raniji prestanak obveznog odnosa ispunjenjem obveza, nego su upravljeni na trajnije obvezivanje, na trajanje obveznog odnosa i njegovo smisleno bivanje u vremenu. ${ }^{37}$

Obvezni odnosi koji nisu trajni obvezni odnosi u švicarskom se pravu nazivaju jednostavnim obveznim odnosima (njem. einfache Schuldverhältnisse), ${ }^{38}$ a taj pojam se redovito rabi isključivo s ciljem razgraničenja trajnih od ostalih obveznih odnosa. ${ }^{39}$ Jednostavni obvezni odnosi iscrpljuju se jednokratnom razmjenom činidbi koja je cilj radi kojega se takvi obvezni odnosi zasnivaju. ${ }^{40} \mathrm{U}$ tom smislu oni $\mathrm{u}$ austrijskom pravu i označavaju se obveznim odnosi-

34 Usporedi, za švicarsko pravo: ibid.

35 Pojam trenutne, ad hoc ili trenutačne obveze rabi se ponegdje sa značenjem obveze koja prestaje "praktički odmah nakon preuzimanja”: Gorenc, op. cit. u bilj. 7, str. 482.; a u istom smislu: Gorenc, loc. cit. u bilj. 6; Vizner, loc. cit. u bilj. 8; Vizner et al., loc. cit. u bilj. 6.

36 Usporedi, za švicarsko pravo: Binder, A.; Geiser, T.; Roberto, V., Einführung ins Privatrecht, Universität St. Gallen, St. Gallen, 2008., str. 23.; Gauch, op. cit. u bilj. 16, str. 8.; Gauch et al., op. cit. u bilj. 15, str. 21. i 48.; Schwenzer, I., Schweizerisches Obligationenrecht - Allgemeiner Teil, Stämpfli Verlag, Bern, 2003., str. 11.-12. Za austrijsko pravo: Bydlinski, loc. cit. u bilj. 1.; Kletečka, A.; Schauer, M. (ur.), ABGB-ON - Kommentar zum Allgemeinen bürgerlichen Gesetzbuch, Manzsche Verlags- und Universitätsbuchhandlung, Wien, 2010., str. 1548.; Schwimann, M. (ur.), ABGB Taschenkommentar, LexisNexis Verlag, Wien, 2010., str. 520. Za njemačko pravo: Bamberger et al., op. cit. u bilj. 24, § 311, odl. 11.; Krüger, op. cit. u bilj. 24, § 314, odl. 5.; Palandt, loc. cit. u bilj. 3; Werner Lange, K., Schuldrecht AT, C. H. Beck, Bayreuth, 2012., str. 14.; Zerres, loc. cit. u bilj. 28.

37 Usporedi, za švicarsko pravo: Gauch, op. cit. u bilj. 16, str. 7.-8. Za austrijsko pravo: Barta, op. cit. u bilj. 18, str. 388.; Bydlinski, loc. cit. u bilj. 15; Gschnitzer, loc. cit. u bilj. 32. Za njemačko pravo: Bamberger et al., op. cit. u bilj. 24, § 311, odl. 11.; Dauner Lieb; Langen, op. cit. u bilj. 3, § 314, odl. 3. i 8.; Krüger, op. cit. u bilj. 24, § 314, odl. 5.; Larenz, K.; Canaris, C.-W., Methodenlehre der Rechtswissenschaft, Springer-Verlag, Berlin - Heidelberg, 1995., str. 300.; Palandt, loc. cit. u bilj. 3.

38 Tako: Gauch, op. cit. u bilj. 16, str. 4.; Gauch et al., op. cit. u bilj. 15, str. 21. i 48.; Maurenbrecher, B., Das Darlehen als Dauerschuldverhältnis, Recht, god. 21, br. 5, 2003., str. 181.; Schwenzer, op. cit. u bilj. 36, str. 11.

Tako: Gauch, op. cit. u bilj. 16, str. 4.

40 Usporedi: Binder et al., loc. cit. u bilj. 36; Gauch, op. cit. u bilj. 16, str. 7.-8.; Gauch et al., op. cit. u bilj. 15, str. 21.; Schwenzer, op. cit. u bilj. 36, str. 11. 
ma cilja (njem. Zielschuldverhältnisse) ${ }^{41} \mathrm{U}$ njemačkoj pravnoj književnosti von Gierke ih je bio naznačio prolaznim obveznim odnosima (njem. vorübergehende Schuldverhältnisse), ${ }^{42}$ a osim o jednostavnim obveznim odnosima u njemačkoj pravnoj književnosti u tom smislu piše se i o pojedinačnim obveznim odnosima (njem. Einzelschuldverhältnisse) te obveznim odnosima s jednokratnom činidbom (njem. Schuldverhältnisse auf einmalige Leistung). ${ }^{43}$ Pojam trenutnih ugovora ili ugovora s trenutnim činidbama koji se rabi u hrvatskoj pravnoj književnosti, isključivo pri razgraničenju trajnih obveznih odnosa od onih koji nisu trajni, ${ }^{44}$ potrebno je razumjeti sa značenjem jednostavnog obveznog odnosa, odnosno obveznog odnosa cilja. Kako izraz "trenutni" nije prikladan terminološki odabir za označavanje takvih obveznih odnosa jer on upućuje na kratkotrajnost što nije njihovo nužno obilježje, tako se u ovom radu za obvezne odnose koji nisu trajni radi njihova razgraničenja od trajnih obveznih odnosa rabi izraz jednostavni obvezni odnosi, a za obveze iz takvih odnosa izraz jednostavne obveze.

\section{TIPIČNI TRAJNI OBVEZNI ODNOSI}

Predmet tipične trajne obveze u trajnim obveznim odnosima može biti trajna činidba koju je dužnik dužan kontinuirano izvršavati. Takvi trajni obvezni odnosi karakteristično se zasnivaju ugovorima o privremenom prepuštanju predmeta ugovora najmanje na uporabu (njem. Gebrauchsüberlassungsverträge), ${ }^{45} \mathrm{u}$ kojima je predmet trajne obveze ostavljanja na uporabu trajna činidba koja ima oblik trpljenja. U tu skupinu ugovora redovito se ubrajaju, primjerice, ugovori o najmu, ${ }^{46}$ zakupu, ${ }^{47}$ leasingu, ${ }^{48}$ licenciji, ${ }^{49}$ posudbi ${ }^{50}$

41 Tako: Bydlinski, loc. cit. u bilj. 15; Gschnitzer, loc. cit. u bilj. 32; Kletečka i Schauer, loc. cit. u bilj. 36; Koziol et al., op. cit. u bilj. 15, str. 785.; Schwimann, loc. cit. u bilj. 36.

42 Gierke, op. cit. u bilj. 2, str. 356.

43 Usporedi: Krüger, op. cit. u bilj. 24, § 314, odl. 5.; Larenz i Canaris, loc. cit. u bilj. 37; Werner Lange, loc. cit. u bilj. 36; Zerres, loc. cit. u bilj. 28.

44 Vidi supra u bilj. 6 i tekstu rada u vezi s tom bilješkom.

45 Usporedi, za švicarsko pravo: Gauch, op. cit. u bilj. 16., str. 10. Za austrijsko pravo: Dullinger, loc. cit. u bilj. 19. Za njemačko pravo: Gitter, W., Gebrauchsüberlassungsverträge, J. C. B. Mohr Verlag, Tübingen, 1988., str. 7.; Oetker, H., Das Dauerschuldverhältnis und seine Beendigung, Mohr Siebeck, Tübingen, 1994., str. 145.; Oetker, H.; Maultzsch, F., Vertragliche Schuldverhältnisse, Springer, Berlin - Heidelberg, 2013., str. 9.

46 Tako, npr., za hrvatsko pravo: Crnić, op. cit. u bilj. 14., str. 420.; za švicarsko pravo: Gauch et al., op. cit. u bilj. 15, str. 48.; za austrijsko pravo: Koziol et al., op. cit. u bilj. 15, str. 1225.; za njemačko pravo: Oetker; Maultzsch, op. cit. u bilj. 45, str. 271.

47 Tako, npr., za hrvatsko, švicarsko, austrijsko i njemačko pravo: ibid. Iz hrvatske sudske prakse, vidi odluke: VSRH, Rev 801/06-2 od 10. srpnja 2007. "Treba međutim imati na umu da se ugovorom o zakupu zasniva trajni obvezni odnos." VSRH, Rev 1290/082 od 27. svibnja 2013. "U ocjeni odnosa između ugovornih stranaka treba imati na umu da se ugovorom o zakupu zasniva trajni obvezni odnos."

48 Tako, npr., za hrvatsko pravo: Tot, I., Operativni leasing, doktorski rad, Pravni fakultet Sveučilišta u Zagrebu, Zagreb, 2016. str. 222.-223. i 322.; za švicarsko pravo: Schwenzer, op. cit. u bilj. 36, str. 12.; za austrijsko pravo: Koziol et al., op. cit. u bilj. 15, str. 1197.; za njemačko pravo: Greiner, S., Schuldrecht Besonderer Teil - Vertragliche Schuldverhältnisse, Springer Verlag, Berlin Heidelberg, 2011., str. 252.-253.

49 Tako, npr., za hrvatsko pravo: Gorenc, V.; Kačer, H.; Momčinović, H.; Slakoper, Z.; Vukmir, B.; Belanić, L., Obvezno pravo - Posebni dio I. - Pojedini ugovori, Novi informator, Zagreb, 2012., str. 249.; za švicarsko pravo: Bucher, E., Obligationenrecht - Besonderer Teil, Schulthess Polygraphischer Verlag, Zürich, 1988., str. 41.; za austrijsko pravo: Kletečka; Schauer, op. cit. u bilj. 36, str. 2039. za njemačko pravo: Gitter, op. cit. u bilj. 45, str. 431.

50 Tako, npr., za hrvatsko pravo: Gorenc et al., op. cit. u bilj. 49, str. 142.; za švicarsko pravo: Gauch et al., op. cit. u bilj. 15, str. 48.; za austrijsko pravo: Apathy, P.; Riedler, A., Bürgerliches Recht - Band III - Schuldrecht - Besonderer Teil, Springer, Wien - New York, 
i zajmu, ${ }^{51}$ a od ugovora koji nisu u hrvatskom pravu zakonom uređeni kao posebni tipovi ugovora, primjerice, ugovori o franchisingu, ${ }^{52}$ o postavljanju samoposlužnih uređaja (njem. Automatenaufstellungsvertrag $)^{53}$ i o udomiteljskom smještaju (njem. Heimvertrag)..$^{54}$

Trajna činidba predmet je trajne obveze i u obveznim odnosima koji se zasnivaju pojedinim tipovima ugovora s činidbom rada koja za objekt ima funkciju rada (njem. Arbeitsverträge; Tätigkeitsverträgen). ${ }^{55}$ Takvi su, primjerice, ugovori o radu, ${ }^{56}$ ostavi i uskladištenju, ${ }^{57}$ kao i ugovor o službi (njem. Dienstvertrag) ${ }^{58}$ te ugovor o skrbi o tuđem poslu (njem. Geschäftsbesorgungsvertrag) ako on ima karakter ugovora o službi. ${ }^{59}$

2010., str. 68; za njemačko pravo: Oetker i Maultzsch, op. cit. u bilj. 45, str. 438.

51 Tako, npr., za hrvatsko pravo: Gorenc et al., op. cit. u bilj. 49, str. 201.; za švicarsko pravo: Maurenbrecher, loc. cit. u bilj. 38; za austrijsko pravo: Koziol et al., op. cit. u bilj. 15, str. 1075.; za njemačko pravo: Oetker i Maultzsch, op. cit. u bilj. 45, str. 271.

52 Tako, npr., za austrijsko pravo: Barta, op. cit. u bilj. 18, str. 388.; za njemačko pravo: Gitter, op. cit. u bilj. 45, str. 431.; Oetker, op. cit. u bilj. 45, str. 175. U hrvatskoj sudskoj praksi vidi odluku: VSRH, II Rev-191/00-2 od 2. srpnja 2003. "Naime, iz priloženog ugovora o poslovnoj suradnji u čl. 1. proizlazi obveza tuženika na plaćanje naknade davatelju 'franšize' koja se sastoji od prava na obavljanje stručne kancelarijske, financijske te tehničke pomoći i dr. Dakle, radi se o trajnim obveznim odnosima kod kojih svaka strana može takav odnos prekinuti otkazom (...)."

53 Tako, npr., za švicarsko pravo: Honsell, H.; Vogt, N. P.; Wiegand, W. (ur.), Basler Kommentar zum Schweizerischen Privatrecht - Obligationenrecht I - Art. 1-529 OR, Helbing \& Lichtenhahn, Basel - Genf - München, 2003., str. 985.; za njemačko pravo: Gitter, op. cit. u bilj. 45, str. 258.; Palandt, loc. cit. u bilj. 3. U hrvatskoj sudskoj praksi vidi odluku: Visoki trgovački sud Republike Hrvatske, Pž-5315/09-3 od 7. veljače 2014. "Nije sporno da je tuženik (...) otkazao tužitelju Ugovor o postavljanju automata za prodaju toplih napitaka pozivajući se na otkazni rok od 60 dana (...) koji rok su stranke ugovorom u trajnom obveznom odnosu odredile, iz čega proizlazi da je istekom toga otkaznog roka (...) prestao ugovor, a time i prava i obveze stranaka.”

54 Tako, npr., za austrijsko pravo: Koziol et al., op. cit. u bilj. 15, str. 2002.; za njemačko pravo: Gitter, op. cit. u bilj. 45 , str. 215 U hrvatskoj sudskoj praksi vidi odluku: Županijski sud u Varaždinu, Gž.428/07-2 od 8. svibnja 2007. "Naime, prema čl. 358. st. 1. ZOO-a ako trajanje obveznog odnosa stranaka nije određeno, svaka ga strana može prekinuti otkazom. (...) Kako je sud prvog stupnja donoseći pobijanu presudu pravilno utvrdio da je Ugovor o pružanju usluga u domu i naknadi za smještaj prestao otkazom od strane tužitelja, istekom otkaznog roka od mjesec dana (...)."

55 Usporedi, za švicarsko pravo: Gauch, op. cit. u bilj. 16, str. 11.; za njemačko pravo: Oetker; Maultzsch, loc. cit. u bilj. 45.

56 Tako, npr., za hrvatsko pravo: Crnić, op. cit. u bilj. 14, str. 420.; za švicarsko pravo: Gauch et al., op. cit. u bilj. 15, str. 48.; za austrijsko pravo: Barta, op. cit. u bilj. 18, str. 388.; za njemačko pravo: Krüger, op. cit. u bilj. 24, § 314, odl. 6. O radnom odnosu kao trajnom obveznom odnosu vidi odluke iz hrvatske sudske prakse: VSRH, Revr 533/05-2 od 9. veljače 2006. "Radni odnos je trajni obvezni odnos."; VSRH, Revr 106/08-2 od 2. travnja 2008. "Slijedom toga ugovor o radu prenosi se po samom zakonu pa su stranke obveze iz ugovora o radu, kao trajnog obveznog odnosa, i nadalje dužne ispunjavati u dobroj vjeri.”; Županijski sud u Varaždinu, Gž.274/07-2 od 17. travnja 2007. "Zakon o radu nema izričite odredbe o tome kada nastupa učinak otkaza, dakle kada prestaje radni odnos, ali budući da je ugovor o radu trajni obvezni odnos koji može prestati i otkazom u smislu odredaba obveznog prava, ugovor o radu na temelju izvanrednog otkaza prestaje danom dostave otkaza, jer kod takvog otkaza nije propisana mogućnost otkaznog roka."

57 Tako, npr., za švicarsko pravo: Gauch et al., op. cit. u bilj. 15, str. 48.; Honsell et al., op. cit. u bilj. 53, str. 2523.; za austrijsko pravo: Apathy i Riedler, op. cit. u bilj. 50, str. 56.; za njemačko pravo: Oetker, op. cit. u bilj. 45, str. 154.; Oetker; Maultzsch, op. cit. u bilj. 45., str. 717. Suprotno, u hrvatskoj pravnoj književnosti, ugovor o ostavi u tzv. trenutačne ugovore ubrajaju: Gorenc, loc. cit. u bilj. 6; Vizner et al., loc. cit. u bilj. 6. Ugovorom o ostavi zasniva se trajni obvezni odnos jer obveza čuvanja ima prirodu trajne obveze, a istovjetno je i kod ugovora o uskladištenju.

58 Tako, npr., za švicarsko pravo: Gauch, op. cit. u bilj. 16, str. 11.; za austrijsko pravo: Apathy i Riedler, op. cit. u bilj. 50, str. 41.; Bydlinski, loc. cit. u bilj. 15; za njemačko pravo: Oetker, op. cit. u bilj. 45, str. 152.; Oetker; Maultzsch, op. cit. u bilj. 45 , str. 455.

59 Tako, npr., za njemačko pravo: Oetker, op. cit. u bilj. 45, str. 160. Ugovor o pružanju odvjetničkih usluga je prema svojoj pravnoj prirodi ugovor o skrbi o tuđem poslu, a za ugovor o pružanju odvjetničkih usluga kao trajni obvezni odnos vidi u hrvatskoj sudskoj praksi odluku: VSRH, Rev-2268/00-2 od 22. listopada 2003. "Prema čl. 357. ZOO-a trajni dugovinski što znači obvezni odnos s određenim rokom trajanja prestaje kad rok istekne. U ovom slučaju ugovor o pružanju odvjetničkih usluga (...) zaključen je na vrijeme od dvije godine što znači do 1. rujna 2000. godine time, da se za slučaj da ga do isteka roka ni jedna strana pismeno ne otkaže isti smatra produženim pod identičnim ugovornim uvjetima (...)." 
Trajni obvezni odnos zasniva se i ugovorom o ortaštvu u kojemu tipična obveza sudjelovanja u ostvarivanju zajedničkog cilja ima karakter trajne obveze. ${ }^{60}$

Trajni obvezni odnosi zasnivaju se i pojedinim tipovima ugovora koji se ponegdje u poredbenoj pravnoj književnosti uključuju u skupinu tzv. ugovora o pripravnosti na činidbu (njem. Leistungsbereitschaftsverträge) ${ }^{61}$ Takvi su, primjerice, ugovor o jamstvu, ${ }^{62}$ ugovor o doživotnom uzdržavanju, ${ }^{63}$ ugovor o dosmrtnom uzdržavanju ${ }^{64}$ i ugovor o osiguranju. ${ }^{65}$

Trajni obvezni odnosi su i obvezni odnosi u kojima je predmet tipične trajne obveze ponavljanje jednokratnih činidbi. Takvi odnosi zasnivaju se ugovorima s uzastopnim isporukama ako je obveza isporuke trajna obveza čiji opseg nije unaprijed određen i ograničen brojem pojedinih isporuka, nego je ovisan o vremenu trajanja ugovornog odnosa. ${ }^{66}$

Trajni obvezni odnosi su i obvezni odnosi koji se zasnivaju ugovorima o opskrbi (njem. Bezugsverträge), kao što su to ugovori o opskrbi vodom, plinom, električnom energijom i sl. ${ }^{67} \mathrm{Za}$ njih je karakteristično da nisu upravljeni na ispunjenje ukupne obveze isporuke, nego na trajnu obvezu opskrbe čiji opseg u pojedinim vremenskim razmacima prema svojim potrebama određuje vjerovnik te obveze, pri čemu se opseg novčane obveze kao protučinidbe obračunava u vremenskim razmacima prema stvarnoj potrošnji. Ugovore o opskrbi se ponegdje svrstava u tzv. ponavljajuće obvezne odnose (njem. Wiederkehrschuldverhältnisse), koje se opisuje kao ponavljanje sklapanja ugovora za određeno obračunsko razdoblje te ističe da se oni razlikuju od ugovora s uzastopnim isporukama za koji je karakteristično da je riječ o jednom jedinstvenom ugovoru. ${ }^{68}$ Nasuprot tome, drži se da pojam ponavljajućih obveznih odnosa nije prihvatljiv jer se ovdje redovito radi o obveznom odnosu koji je utemeljen na osnovnom ili okvirnom ugovoru. ${ }^{69}$

Trajni obvezni odnos zasniva se i okvirnim ugovorom (njem. Rahmenvertrag), ${ }^{70}$ neovisno o tome imaju li pojedini ugovori koji se sklapaju na temelju okvirnog ugovora obilježja trajnih

60 Tako, npr., za hrvatsko pravo: Gorenc et al., op. cit. u bilj. 49, str. 635.-636.; za švicarsko pravo: Gauch, op. cit. u bilj. 16., str. 15.; Schwenzer, op. cit. u bilj. 36, str. 12.; za austrijsko pravo: Apathy i Riedler, op. cit. u bilj. 50., str. 146.; za njemačko pravo: Oetker, op. cit. u bilj. 45, str. 166.-167.

61 Tako, npr.: Oetker, op. cit. u bilj. 45, str. 168.

62 Tako, npr., za austrijsko pravo: Koziol et al., op. cit. u bilj. 15, str. 1620; za njemačko pravo: Oetker, op. cit. u bilj. 45, str. 168.

63 Tako, npr., za švicarsko pravo: Gauch, op. cit. u bilj. 16, str. 14.; Gauch et al., op. cit. u bilj. 15, str. 48.; za njemačko pravo: Oetker, op. cit. u bilj. 45 , str. 169 .

64 Tako, npr., za njemačko pravo: Oetker, op. cit. u bilj. 45, str. 170.

65 Tako, npr., za hrvatsko pravo: Gorenc et al., op. cit. u bilj. 49, str. 699.; za austrijsko pravo: Barta, op. cit. u bilj. 18, str. 388.; za njemačko pravo: Oetker, op. cit. u bilj. 45, str. 171.

66 Tako, npr., za švicarsko pravo: Schwenzer, op. cit. u bilj. 36, str. 12.; za austrijsko pravo: Dullinger, op. cit. u bilj. 19, str. 43.; za njemačko pravo: Bamberger et al., op. cit. u bilj. 24, § 314, odl. 6.; Fikentscher, loc. cit. u bilj. 1.; Gierke, op. cit. u bilj. 2, str. 362.; Stürner, loc. cit. u bilj. 15.

67 Tako, npr., za švicarsko pravo: Gauch et al., op. cit. u bilj. 15, str. 48.; za austrijsko pravo: Apathy; Riedler, op. cit. u bilj. 50, str. $5 . ;$ Barta, op. cit. u bilj. 18, str. 388.; Bydlinski, loc. cit. u bilj. 15; za njemačko pravo: Dauner-Lieb; Langen, op. cit. u bilj. 3, §314, odl. 11.; Krüger, loc. cit. u bilj. 24, §314, odl. 8.; Oetker, op. cit. u bilj. 45, str. 175. Tako, za njemačko pravo: Stürner, op. cit. u bilj. 15, § 311, odl. 15.

69 Tako, za njemačko pravo: Oetker, op. cit. u bilj. 45, str. 170.

70 Tako, za njemačko pravo: Dauner-Lieb; Langen, op. cit. u bilj. 3, § 311, odl. 35. i § 314, odl. 10.; Krüger, op. cit. u bilj. 24, § 314 odl. 7.; Hoffbauer, C., Der Rahmenvertrag in der Lieferbeziehung, Logos Verlag, Berlin, 2010., str. 19. Tako i: Perović; Stojanović, op. cit. u bilj. 6, str. 421. 
obveznih odnosa ili ne. Za okvirne ugovore karakteristična je trajna obveza suradnje koja prestaje prestankom trajnog obveznog odnosa.

Ugovorima s isporukom u dijelovima (njem. Teillieferungsverträge) i ugovorima s obročnim otplatama (njem. Ratenverträge) ne zasnivaju se trajni obvezni odnosi. ${ }^{71}$ Takvim ugovorima nastaju jednostavni obvezni odnosi upravljeni na jednokratnu razmjenu činidbi, ali su ugovorne strane ugovorom ovlaštene, umjesto jednokratno, svoju činidbu ispuniti višekratno u unaprijed određenom i ograničenom broju dijelova, odnosno obroka. ${ }^{72}$

\section{POSEBNOSTI TRAJNIH OBVEZNIH ODNOSA}

Opće zakonsko uređenje obveznih odnosa u švicarskom, austrijskom i njemačkom pravu usmjereno je ponajprije na uređenje jednostavnih obveznih odnosa, a ne trajnih obveznih odnosa. ${ }^{73}$ Istovjetno je i u hrvatskom pravu, uz specifičnost što je u hrvatskom pravu u odredbama čl. 211. i čl. 212. ZOO-a sadržano opće uređenje prestanka trajnih obveznih odnosa. Prema tom općem uređenju trajni obvezni odnosi ne prestaju ispunjenjem, nego protekom vremena i redovnim otkazom kao redovnim načinima prestanka trajnih obveznih odnosa koji djeluju samo pro futuro i za posljedicu nemaju nastanak obveze vraćanja onoga što je ispunjeno prije prestanka trajnog obveznog odnosa. Zbog tih odredaba u hrvatskom pravu ne postoji potreba za izvođenjem općih pravila o redovnim načinima prestanka trajnih obveznih odnosa iz pojedinih odredaba kojima su uređeni načini prestanka pojedinih trajnih obveznih odnosa, a koja postoji u švicarskom, austrijskom i njemačkom pravu. ${ }^{74}$ Međutim, kao i u poredbenom pravu, i u hrvatskom pravu je potrebno ispitivati mogu li se ostale odredbe općeg uređenja obveznih odnosa koje primarno uređuju jednostavne obvezne odnose primijeniti na trajne obvezne odnose izravno ili samo analogijom, odnosno mogu li se one uopće primijeniti na trajne obvezne odnose, imajući u vidu posebnu prirodu takvih odnosa.

S tim u vezi, bitno je istaknuti kako se uz posebnost trajnih obveznih odnosa koja se ogleda u načinima i učincima njihova prestanka, ${ }^{75}$ kao druga ključna posebnost trajnih obveznih odnosa prema jednostavnim obveznim odnosima redovito u švicarskom, austrijskom i njemačkom pravu ističe i ograničenost učinaka nevaljanosti trajnih obveznih odnosa. U švicarskom

71 Suprotno, u pravnoj književnosti u kontekstu ZOO-a i ZOO-a/78: Gorenc, loc. cit. u bilj. 6; Perović; Stojanović, op. cit. u bilj. 6, str. 421.; Vizner et al., loc. cit. u bilj. 6.

72 Usporedi, za švicarsko pravo: Gauch et al., op. cit. u bilj. 15, str. 21.; Schwenzer, op. cit. u bilj. 36, str. 12. Za austrijsko pravo: Dullinger, op. cit. u bilj. 19, str. 43. Za njemačko pravo: Dauner-Lieb; Langen, op. cit. u bilj. 3, § 314, odl. 6.-7.; Gierke, op. cit. u bilj. 2, str. 358.; Krüger, loc. cit. u bilj. 24; Zerres, loc. cit. u bilj. 28.

73 Tako za opći dio švicarskog OR-a: Bucher, E., Schweizerisches Obligationenrecht - Allgemeiner Teil ohne Deliktsrecht, Schulthess Polygraphischer Verlag, Zürich, 1988., str. 102.; Dasser, F., Vertragsrecht ohne Vetragstypenrecht?, u: Honsell, H.; Portmann, W.; Zäch, R.; Zobl, D. (ur.), Aktuelle Aspekte des Schuld- und Sachenrechts - Festschrift für Heinz Rey zum 60. Geburtstag, Schulthess, Zürich, 2003., str. 212. Tako za odredbe ABGB-a: Dullinger, op. cit. u bilj. 19, str. 38.; Mayer-Maly, T., Einführung in die Rechtswissenschaft, Springer Verlag, Berlin - Heidelberg, 1993., str. 94. Tako za odredbe BGB-a: Bamberger et al., op. cit. u bilj. 24, § 311, odl. 11.; Gierke, op. cit. u bilj. 2, str. 356.-357.; Larenz; Canaris, op. cit. u bilj. 37, str. 301.; Stürner, op. cit. u bilj. 15, § 311, odl. 16.; Zerres, loc. cit. u bilj. 28. Tako, primjerice, za švicarsko pravo: Gauch, op. cit. u bilj. 16, str. 37.; za njemačko pravo: Oetker; Maultzsch, op. cit. u bilj. 45, str. 391. 
pravu drži se da su, u slučajevima u kojima su ugovorne strane već započele s ispunjavanjem ugovornih obveza, učinci ništetnosti i pobojnosti kod trajnih obveznih odnosa ograničeni na djelovanje samo pro futuro jer bi u tim slučajevima bilo gospodarski nerazumno kad bi ugovorne strane, koje su s povjerenjem u postojanje trajnog obveznog odnosa izvršile pojedine činidbe, bile obvezne na vraćanje tih činidaba zbog načelnih ex tunc učinaka ništetnosti i pobojnosti. ${ }^{76}$ Gledište o ex nunc učincima nevaljanosti trajnih obveznih odnosa koji se nalaze u stadiju ispunjavanja pretežu i u austrijskom te njemačkom pravu. ${ }^{77}$ Ispitivanje prihvatljivosti takvog gledišta za hrvatsko pravo nije predmetom ovog rada i ostavlja se za nastavak istraživanja.

\section{ZAKLJUČAK}

Trajni obvezni odnosi obvezni su odnosi u kojima je tipična glavna obveza trajna obveza, a trajna obveza je obveza koja za predmet ima trajnu činidbu ili trajno ponavljanje jednokratnih činidbi u određenim vremenskim razmacima. Trajna činidba je radnja koju je dužnik na temelju trajnog obveznog odnosa dužan neprekidno, kontinuirano izvršavati. Trajni obvezni odnosi u kojima je predmet trajne obveze ponavljanje jednokratnih činidbi zasnivaju se takvim ugovorima s uzastopnim isporukama u kojima opseg trajne obveze uzastopnih isporuka nije unaprijed određen i ograničen brojem pojedinih isporuka, nego je ovisan o vremenu trajanju ugovornog odnosa. Takve ugovore s uzastopnim isporukama preciznije je potrebno odrediti kao ugovore s trajnom isporukom.

Trajni obvezni odnosi ne zasnivaju se ugovorima s uzastopnim isporukama u kojima je unaprijed određen i ograničen broj pojedinih isporuka i broj dijelova ili obroka protučinidbe, a u kojima ponavljanja jednokratnih činidbi i protučinidbi u određenim vremenskim razmacima imaju značenje djelomičnih ispunjenja ugovornih obveza. Trajni obvezni odnosi ne zasnivaju se ni ugovorima s isporukom u dijelovima ili obrocima niti ugovorima s obročnim otplatama, a takvim ugovorima nastaju jednostavni obvezni odnosi koji su upravljeni na jednokratnu razmjenu činidbi, ali je jedna ugovorna strana ugovorom ovlaštena, umjesto jednokratno, svoju činidbu ispuniti višekratno u unaprijed određenom i ograničenom broju dijelova, odnosno obroka.

Zakonsko uređenje obveznih odnosa u hrvatskom pravu, jednako kao i u švicarskom, austrijskom i njemačkom pravu, usmjereno je ponajprije na uređenje jednostavnih obveznih odnosa. Pravni instituti općeg dijela obveznog prava uređeni su zakonom na način koji obveznopravni odnos promatra kroz prizmu jednostavnih obveznih odnosa, a ne trajnih obveznih odnosa. Stoga je pri njihovoj primjeni na trajne obvezne odnose potrebno ispitivati mogu li se oni primijeniti na trajne obvezne odnose s obzirom na posebnu prirodu i obilježja tih obveznih odnosa, odnosno mogu li se oni na trajne obvezne odnose primijeniti izravno ili samo analogijom.

76 Usporedi: Binder et al., op. cit. u bilj. 36, str. 56. i 61.; Gauch et al., op. cit. u bilj. 15, str. 191.; Honsell et al., op. cit. u bilj. 53, str. 232. i 248.; Schwenzer, op. cit. u bilj. 36, str. 12., 204., 219. i 259.; Wiegand, W., Zur Rückabwicklung gescheiterter Verträge, u: Tercier, P.; Amstutz, M.; Koller, A.; Schmid, J.; Stöckli, H. (ur.), Gauchs Welt - Festschrift für Peter Gauch zum 65. Geburtstag, Schulthess, Zürich, 2004., str. 714.-717.

77 Vidi, za austrijsko pravo: Bydlinski, loc. cit. u bilj. 15., str. 180.; Gschnitzer, op. cit. u bilj. 32, str. 160.-161.; Kletečka; Schauer, op. cit. u bilj. 36, str. 1548. i 1654.; Koziol et al., op. cit. u bilj. 15, str. 831.; Koziol, H.; Welser, R.; Kletečka, A., Grundriss des bürgerlichen Rechts - Band I - Allgemeiner Teil, Sachenrecht, Familienrecht, MANZ'sche Verlags- und Universitätsbuchhandlung, Wien, 2014., str. 176.-177. Vidi, za njemačko pravo: Larenz; Canaris, op. cit. u bilj. 37, str. 215.; Zerres, op. cit. u bilj. 28 , str. 69. 


\section{LITERATURA}

1. Apathy, P., Riedler, A., Bürgerliches Recht - Band III - Schuldrecht - Besonderer Teil, Springer, Wien New York, 2010.

2. Bamberger, H. G., Roth, H., Hau, W., Poseck, R., BeckOK BGB, Verlag C. H. Beck, München, 2017.

3. Barta, H. (ur.), Zivilrecht - Grundriss und Einführung in das Rechtsdanken, Facultas Verlags- und Buchhandels, Wien, 2004.

4. Binder, A., Geiser, T., Roberto, V., Einführung ins Privatrecht, Universität St. Gallen, St. Gallen, 2008.

5. Bucher, E., Schweizerisches Obligationenrecht - Allgemeiner Teil ohne Deliktsrecht, Schulthess Polygraphischer Verlag, Zürich, 1988.

6. Bucher, E., Obligationenrecht - Besonderer Teil, Schulthess Polygraphischer Verlag, Zürich, 1988.

7. Bydlinski, P., Bürgerliches Recht - Band I-Allgemeiner Teil, Springer, Wien - New York, 2007.

8. Cigoj, S., Komentar obligacijskih razmerij-I. knjiga, Časopisni zavod Uradni list SR Slovenije, Ljubljana, 1984.

9. Crnić, I., Zakon o obveznim odnosima, Organizator, Zagreb, 2016.

10. Dasser, F., Vertragsrecht ohne Vetragstypenrecht?, u: Honsell, H., Portmann, W., Zäch, R., Zobl, D. (ur.), Aktuelle Aspekte des Schuld- und Sachenrechts - Festschrift für Heinz Rey zum 60. Geburtstag, Schulthess, Zürich, 2003., str. 207.-216.

11. Dauner-Lieb, B., Langen, W. (ur.), BGB - Schuldrecht - Band 2, Nomos, Baden-Baden, 2016.

12. Dullinger, S., Bürgerliches Recht - Band II - Schuldrecht - Allgemeiner Teil, Springer, Wien - New York, 2010.

13. Fikentscher, W., Schuldrecht, Walter de Gruyter, Berlin - New York, 1992.

14. Gauch, P., System der Beendigung von Dauerverträgen, Universitätsverlag Freiburg, Freiburg, 1968.

15. Gauch, P., Schluep, W. R., Schmid, J., Rey, H., Schweizerisches Obligationenrecht - Allgemeiner Teil Band I, Schulthess Polygraphischer Verlag, Zürich, 1998.

16. Gierke von, O., Dauernde Schuldverhältnisse, Jherings Jahrbücher für die Dogmatik des bürgerlichen Rechts, god. 64, 1914., str. 355.-411.

17. Gitter, W., Gebrauchsüberlassungsverträge, J. C. B. Mohr Verlag, Tübingen, 1988.

18. Gorenc, V., Trgovačko pravo - ugovori, Školska knjiga, Zagreb, 1997.

19. Gorenc, V., Zakon o obveznim odnosima s komentarom, RRIF Plus, Zagreb, 1998.

20. Gorenc, V., Kačer, H., Momčinović, H., Slakoper, Z., Vukmir, B., Belanić, L., Obvezno pravo - Posebni dio I. - Pojedini ugovori, Novi informator, Zagreb, 2012.

21. Greiner, S., Schuldrecht Besonderer Teil - Vertragliche Schuldverhältnisse, Springer Verlag, Berlin Heidelberg, 2011.

22. Gschnitzer, F., Schuldrecht - Besonderer Teil und Schadenersatz, Springer Verlag, Wien, 1963.

23. Hoffbauer, C., Der Rahmenvertrag in der Lieferbeziehung, Logos Verlag, Berlin, 2010.

24. Honsell, H., Vogt, N. P., Wiegand, W. (ur.), Basler Kommentar zum Schweizerischen Privatrecht - Obligationenrecht I - Art. 1-529 OR, Helbing \& Lichtenhahn, Basel - Genf - München, 2003.

25. Kačer, H., Radolović, A., Slakoper, Z., Zakon o obveznim odnosima s komentarom, Poslovni zbornik, Zagreb, 2006.

26. Klarić, P., Vedriš, M., Građansko pravo, Narodne novine, Zagreb, 2009.

27. Kletečka, A., Schauer, M. (ur.), ABGB-ON - Kommentar zum Allgemeinen bürgerlichen Gesetzbuch, Manzsche Verlags- und Universitätsbuchhandlung, Wien, 2010. 
28. Konstantinović, M., Obligacije i ugovori - Skica za Zakonik o obligacijama i ugovorima, Pravni fakultet u Beogradu, Beograd, 1969.

29. Koziol, H., Bydlinski, P., Bollenberger, R. (ur.), Kurzkommentar zum ABGB, Springer, Wien - New York, 2010.

30. Koziol, H., Welser, R., Kletečka, A., Grundriss des bürgerlichen Rechts - Band I - Allgemeiner Teil, Sachenrecht, Familienrecht, MANZ'sche Verlags- unf Universitätsbuchhandlung, Wien, 2014.

31. Krüger, W. (red.), Münchener Kommentar zum Bürgerlichen Gesetzbuch - Band 2 - Schuldrecht - Allgemeiner Teil, Verlag C. H. Beck, München, 2016.

32. Larenz, K., Canaris, C.-W., Methodenlehre der Rechtswissenschaft, Springer-Verlag, Berlin - Heidelberg, 1995.

33. Maurenbrecher, B., Das Darlehen als Dauerschuldverhältnis, Recht, god. 21, br. 5, 2003, str. 180.-192.

34. Mayer-Maly, T., Einführung in die Rechtswissenschaft, Springer Verlag, Berlin - Heidelberg, 1993.

35. Oetker, H., Das Dauerschuldverhältnis und seine Beendigung, Mohr Siebeck, Tübingen, 1994.

36. Oetker, H., Maultzsch, F., Vertragliche Schuldverhältnisse, Springer, Berlin - Heidelberg, 2013.

37. Palandt, O. (red.), Palandt - Bürgerliches Gesetzbuch, Verlag C. H. Beck, München, 2003.

38. Perović, S., Obligaciono pravo - Knjiga prva, Službeni list SFRJ, Beograd, 1981.

39. Perović, S., Stojanović, D. (red.), Komentar Zakona o obligacionim odnosima - Knjiga prva, Kulturni centar Gornji Milanovac i Pravni fakultet Kragujevac, Novi Sad, 1980.

40. Radišić, J., Obligaciono pravo - Opšti deo, Savremena administracija, Beograd, 1990.

41. Schneider, A., Vertragsanpassung im bipolaren Dauerschuldverhältnis, Mohr Siebeck, Tübingen, 2016.

42. Schwenzer, I., Schweizerisches Obligationenrecht - Allgemeiner Teil, Stämpfli Verlag, Bern, 2003.

43. Schwimann, M. (ur.), ABGB Taschenkommentar, LexisNexis Verlag, Wien, 2010.

44. Slakoper, Z., Gorenc, V., Bukovac Puvača, M., Obvezno pravo - Opći dio - Sklapanje, promjene $i$ prestanak ugovora, Novi informator, Zagreb, 2009.

45. Stürner, R. (red.), Jauernig - Bürgerliches Gezetzbuch: Kommentar, C. H. Beck, München, 2015.

46. Tot, I., Operativni leasing, doktorski rad, Pravni fakultet Sveučilišta u Zagrebu, Zagreb, 2016.

47. Vizner, B., Komentar Zakona o obveznim (obligacionim) odnosima - Knjiga I - Član 1 - 157, Riječka tiskara, Zagreb, 1978.

48. Vizner, B., Komentar Zakona o obveznim (obligacionim) odnosima - Knjiga II - Član 158 - 453, Riječka tiskara, Zagreb, 1978.

49. Vizner, B., Kapor, V., Carić, S., Ugovori građanskog i privrednog prava, Riječka tiskara, Rijeka, 1971.

50. Werner Lange, K., Schuldrecht AT, C. H. Beck, Bayreuth, 2012.

51. Wiegand, W., Zur Rückabwicklung gescheiterter Verträge, u: Tercier, P., Amstutz, M., Koller, A., Schmid, J., Stöckli, H. (ur.), Gauchs Welt - Festschrift für Peter Gauch zum 65. Geburtstag, Schulthess, Zürich, 2004., str. 709.-722.

52. Zerres, T., Bürgerliches Recht, Springer, Berlin - Heidelberg, 2010. 


\section{POPIS PROPISA I SUDSKIH ODLUKA}

1. Zakon o obveznim odnosima, Narodne novine, broj 35/2005, 41/2008, 125/2011, 78/2015 i $29 / 2018$

2. Zakon o obveznim odnosima, Službeni list SFRJ, broj 29/1978, 39/1985 i 57/1989, Narodne novine, br. 53/1991, 73/1991, 111/1993, 3/1994, 7/1996, 91/1996, 112/1999 i 88/2001.

3. Vrhovni sud Republike Hrvatske, Rev-558/1997-2 od 24. kolovoza 2000., dostupno na: Vrhovni sud Republike Hrvatske, Sudska praksa - Portal sudske prakse, URL=https://sudskapraksa.csp.vsrh. hr, pristupljeno 15. siječnja 2018.

4. Vrhovni sud Republike Hrvatske, Revt-18/03-2 od 1. travnja 2003. dostupno na: Vrhovni sud Republike Hrvatske, Sudska praksa - Portal sudske prakse, URL=https://sudskapraksa.csp.vsrh.hr, pristupljeno 15. siječnja 2018.

5. Vrhovni sud Republike Hrvatske, II Rev-191/00-2 od 2. srpnja 2003., dostupno na: Vrhovni sud Republike Hrvatske, Sudska praksa - Portal sudske prakse, URL=https://sudskapraksa.csp.vsrh.hr, pristupljeno 15. siječnja 2018.

6. Vrhovni sud Republike Hrvatske, Rev-2268/00-2 od 22. listopada 2003., dostupno na: Vrhovni sud Republike Hrvatske, Sudska praksa - Portal sudske prakse, URL=https://sudskapraksa.csp.vsrh.hr, pristupljeno 15. siječnja 2018.

7. Vrhovni sud Republike Hrvatske, Revr 533/05-2 od 9. veljače 2006., dostupno na: Vrhovni sud Republike Hrvatske, Sudska praksa - Portal sudske prakse, URL=https://sudskapraksa.csp.vsrh.hr, pristupljeno 15. siječnja 2018.

8. Vrhovni sud Republike Hrvatske, Rev 801/06-2 od 10. srpnja 2007., dostupno na: Vrhovni sud Republike Hrvatske, Sudska praksa - Portal sudske prakse, URL=https://sudskapraksa.csp.vsrh.hr, pristupljeno 15. siječnja 2018.

9. Vrhovni sud Republike Hrvatske, Revr 106/08-2 od 2. travnja 2008., dostupno na: Vrhovni sud Republike Hrvatske, Sudska praksa - Portal sudske prakse, URL=https://sudskapraksa.csp.vsrh.hr, pristupljeno 15. siječnja 2018.

10. Vrhovni sud Republike Hrvatske, Rev 1081/10-5 od 5. veljače 2013., dostupno na: Vrhovni sud Republike Hrvatske, Sudska praksa - Portal sudske prakse, URL=https://sudskapraksa.csp.vsrh.hr, pristupljeno 15. siječnja 2018.

11. Vrhovni sud Republike Hrvatske, Rev 1290/08-2 od 27. svibnja 2013., dostupno na: Vrhovni sud Republike Hrvatske, Sudska praksa - Portal sudske prakse, URL=https://sudskapraksa.csp.vsrh.hr, pristupljeno 15. siječnja 2018.

12. Visoki trgovački sud Republike Hrvatske, Pž-5315/09-3 od 7. veljače 2014., dostupno na: Vrhovni sud Republike Hrvatske, Sudska praksa - Portal sudske prakse, URL=https://sudskapraksa.csp.vsrh. hr, pristupljeno 15. siječnja 2018.

13. Županijski sud u Varaždinu, Gž.274/07-2 od 17. travnja 2007., dostupno na: Vrhovni sud Republike Hrvatske, Sudska praksa - Portal sudske prakse, URL=https://sudskapraksa.csp.vsrh.hr, pristupljeno 15. siječnja 2018.

14. Županijski sud u Varaždinu, Gž.428/07-2 od 8. svibnja 2007., dostupno na: Vrhovni sud Republike Hrvatske, Sudska praksa - Portal sudske prakse, URL=https://sudskapraksa.csp.vsrh.hr, pristupljeno 15. siječnja 2018. 


\section{THE NOTION OF A CONTINUING OBLIGATION RELATIONSHIP}

\section{Summary}

The paper deals with the definition of the concept of a continuing obligation relationship (continuing contract). Crucial for this definition is the notion of a continuing obligation, as well as notions of a continuing act of performance and of consecutive acts of performance. Both the notion of a continuing obligation and the distinction between the consecutive obligations and the performance of an obligation in parts or instalments have been discussed in the paper. Moreover, it differentiates between the contracts for successive delivery, where the repeating of single acts of performance and counter performance at certain time intervals represent partial fulfilment of the contractual obligations, and the contracts for continuous delivery, where the obligation of successive deliveries is a continuing obligation, the scope of which depends on the duration of the contractual relationship. Based on the views developed in German, Austrian and Swiss laws, the conclusion has been drawn that it is adequate for the Croatian law to define continuing obligation relationships as obligation relationships, where the typical main obligation is a continuing obligation, that is, an obligation the subject of which is a continuing act of performance or continuous repeating of single acts of performance. The paper points out the typical continuing obligation relationships and their key distinctive features from obligation relationships that are not continuing obligation relationships, which are referred to as simple obligation relationships.

Keywords: $\quad$ continuing obligation relationship, continuing act of performance, continuing obligation, consecutive obligations 